\title{
Synthesis, Characterization and Enhanced Photocatalytic Activity of Iron Oxide/Carbon Nanotube/Ag-doped $\mathrm{TiO}_{2}$ Nanocomposites
}

\author{
José O. Marques Neto, ${ }^{a}$ Carlos R. Bellato, ${ }^{* a}$ Carlos H. F. de Souza, ${ }^{a}$ \\ Renê C. da Silva ${ }^{b}$ and Pablo A. Rocha ${ }^{c}$
}

\author{
${ }^{a}$ Departamento de Química, ${ }^{b}$ Departamento de Física and ${ }^{c}$ Departamento de Solos, \\ Universidade Federal de Viçosa (UFV), 36570-900 Viçosa-MG, Brazil
}

\begin{abstract}
A novel magnetically recoverable catalyst $\left(\mathrm{Fe} / \mathrm{MWCNT} / \mathrm{TiO}{ }_{2}-\mathrm{Ag}\right)$ was prepared in this study by a process that involves few steps. Titanium dioxide doped with silver and iron oxide was deposited on support of multi-walled carbon nanotubes (MWCNT). The synthesized catalysts were characterized by inductively coupled plasma mass spectrometry (ICP-MS), $\mathrm{N}_{2}$ adsorption/desorption, X-ray diffraction (XRD), scanning electron microscopy (SEM), energy dispersive spectrometry (EDS), infrared spectroscopy (IR) and UV-Vis diffuse reflectance spectra (DRS). Phenol in aqueous solution $\left(50 \mathrm{mg} \mathrm{L}^{-1}\right)$ was used as a model compound for evaluation of UV-Vis (filter cut off for $\lambda>300 \mathrm{~nm}$ ) photocatalytic activity. The composite catalyst has a high photocatalytic activity, destroying ca. $100 \%$ of phenol and removing $85 \%$ of total organic carbon in an aqueous solution after $180 \mathrm{~min}$. The $\mathrm{Fe} / \mathrm{MWCNT} / \mathrm{TiO}_{2}-\mathrm{Ag}$ catalyst remained stable, presenting an $8 \%$ decrease in phenol degradation efficiency after ten consecutive photocatalytic cycles.
\end{abstract}

Keywords: visible light, photocatalysis, titanium dioxide, magnetic separation, phenol

\section{Introduction}

Among the semiconductors used in heterogeneous photocatalysis, titanium dioxide is that most used due to specific properties, including high photosensitivity, non-toxic nature, chemical stability and relatively low cost. ${ }^{1,2}$ One inherent problem to the use of this catalyst is the electron-hole recombination and its high band-gap value of $3.2 \mathrm{eV}$, limiting its photoactivity at low wavelengths and preventing the use of $\mathrm{TiO}_{2}$ in applications with visible light. ${ }^{3,4}$

Doping of $\mathrm{TiO}_{2}$ with metals such as gold, platinum, rhodium and silver increases the spectrum of radiation absorption by $\mathrm{TiO}_{2}$, allowing for its use with visible light. ${ }^{5}$ Silver has a low cost when compared to other noble metals and has electronic properties that make it a good option for use as a dopant on the surface of $\mathrm{TiO}_{2}$. The working function of silver $(4.26 \mathrm{eV})$ lies below the conduction band $(\mathrm{CB})$ of $\mathrm{TiO}_{2}(4.20 \mathrm{eV}), \mathrm{Au}(4.8 \mathrm{eV})$ and $\mathrm{Pt}(5.3 \mathrm{eV})$, and therefore silver can capture the photogenerated electrons of $\mathrm{TiO}_{2}$, acting as electron traps and avoiding the recombination of the hole-electron pairs. ${ }^{6-8}$

The use of carbon nanotubes as support materials can provide functional properties, such as increase of the

*e-mail: bellato@ufv.br specific surface area, high mechanic strength and high conductivity due to their remarkable electrochemical properties. ${ }^{9}$ Carbon nanotubes have high electron storage capacity and may thereby receive the photogenerated electrons from the $\mathrm{TiO}_{2} \mathrm{CB} .{ }^{10}$ The carbon nanotubes when in contact with $\mathrm{TiO}_{2}$ alter its absorption of radiation to longer wavelength light (visible light) due to $\pi \rightarrow \pi^{*}$ transitions of the nanotubes and $\mathrm{n} \rightarrow \pi^{*}$ between the n orbitals of the oxygen of $\mathrm{TiO}_{2}$ and $\pi^{*}$ of the nanotubes. ${ }^{11}$ These unique characteristics of multi-walled carbon nanotubes (MWCNT) have attracted the attention of many researchers in the preparation of nanocomposites with $\mathrm{TiO}_{2}$. The MWCNT properties contribute to facilitate the load transfer, functioning as electron acceptors. ${ }^{12}$

The incorporation of magnetic properties of iron oxides such as magnetite or maghemite in $\mathrm{TiO}_{2}$-based catalysts facilitates its removal from the aqueous solution by application of an appropriate magnetic field, reducing costs and time spent in the extraction of the catalyst to permit its recycling. ${ }^{13,14}$

In addition to its magnetic properties, the iron oxide creates additional energy levels to capture electrons from the conduction band and holes from the valence band of $\mathrm{TiO}_{2}$, promoting a more effective separation of charges and reducing electronic recombination. ${ }^{15}$ 
Several studies have been performed using $\mathrm{TiO}_{2}$ based catalysts with magnetic properties. Zhou et al. ${ }^{14}$ prepared $\mathrm{MWCNT} / \mathrm{Fe}_{3} \mathrm{O}_{4} / \mathrm{TiO}_{2}$ photocatalyst by in situ polymerization with polyacrylic acid and applied it in the phenol photodegradation with UV-Vis light. Luo et al. ${ }^{16}$ fabricated a $\mathrm{TiO}_{2} / \mathrm{Fe}_{3} \mathrm{O}_{4} / \mathrm{MWCNT}$ magnetic catalyst by polymerization method using pyrrole as a support. Zhang et al. ${ }^{17}$ synthesized the $\mathrm{TiO}_{2} / \mathrm{Fe}_{3} \mathrm{O}_{4} / \mathrm{MWNTs}$ catalyst by in situ hydrolysis method and applied for degradation of methylene blue under UV light. Aguilar et al. ${ }^{18}$ prepared $\mathrm{TiO}_{2}-\mathrm{Fe}_{3} \mathrm{O}_{4}$-Ag catalyst doped with silver or gold and evaluated the effectiveness for phenol degradation with UV light and visible light.

There are no reports in the literature on the photocatalytic properties of $\mathrm{Fe} / \mathrm{MWCNT} / \mathrm{TiO}_{2}-\mathrm{Ag}$ composites. In this work, we evaluated the effect of the interaction between iron oxide, silver and MWCNT with regards to the increase of the $\mathrm{TiO}_{2}$ photocatalytic activity, allowing its application with UV-Vis light (cut off filter for $\lambda>300 \mathrm{~nm}$ ). In this study, a new magnetically recoverable composite of $\mathrm{TiO}_{2}$ doped with silver and iron oxide and impregnated on multi-walled carbon nanotubes (10-Fe/MWCNT/TiO ${ }_{2}-\mathrm{Ag}-9$ ) was synthesized by a facile method that involves only a few steps. Furthermore, silver, iron oxide and MWCNT interact with $\mathrm{TiO}_{2}$, thus improving its efficiency for photodegradation of organic compounds. The effect of varying wt.\% of $\mathrm{Ag}$ and $\mathrm{Fe}$ and MWCNT: $\mathrm{TiO}_{2}-\mathrm{Ag}$ wt. ratio on the $\mathrm{Fe} / \mathrm{MWCNT} / \mathrm{TiO}_{2}-\mathrm{Ag}$ composite was evaluated with regards to phenol photodegradation. Phenol is a common organic pollutant in the environment with high toxicity and carcinogenicity, structural stability and resistance to biodegradation. ${ }^{19}$

\section{Experimental}

\section{Materials}

MWCNT were used as received with purity $>93 \%$, outer diameter between 10 and $50 \mathrm{~nm}$ and estimated length of 5 to $30 \mu \mathrm{m}$, produced in the Laboratory of Nanomaterials, Physics Department, at Universidade Federal de Minas Gerais (UFMG), Brazil. The $\mathrm{TiO}_{2}$ used was P25, acquired from Degussa, consisting of $80 \%$ anatase and $20 \%$ rutile. The commercial reagents silver nitrate, ethylene glycol, isopropyl alcohol and phenol were obtained from Sigma-Aldrich. All solutions were prepared with analytical grade reagents and high purity deionized water produced by a Milli-Q ${ }^{\circledR}$ system (Millipore, Bedford, MA, USA).

\section{Preparation of iron oxide}

A solution containing $1.6 \mathrm{~L}$ of water, $2.0 \mathrm{~g}$ of $\mathrm{FeCl}_{3} \cdot 6 \mathrm{H}_{2} \mathrm{O}$ and $4.8 \mathrm{~g}$ of $\mathrm{FeSO}_{4} \cdot 7 \mathrm{H}_{2} \mathrm{O}$ was heated to $70^{\circ} \mathrm{C}$.
Next, $120 \mathrm{~mL}$ of a solution of $5 \mathrm{~mol} \mathrm{~L}^{-1} \mathrm{NaOH}$ were added to the solution containing $\mathrm{Fe}$ salts, causing iron oxide precipitation. The obtained solid was washed with water to $\mathrm{pH} 7.0$ and then dried at $70{ }^{\circ} \mathrm{C}$ for $18 \mathrm{~h} .^{20}$

\section{Preparation of the $\mathrm{Fe} / \mathrm{MWCNT} / \mathrm{TiO} \mathrm{O}_{2}$-Ag catalyst}

The silver nanoparticles (Ag NPs) were deposited on the surface of the commercial $\mathrm{TiO}_{2}$ (Degussa P25) according to the photodeposition method, in which $\mathrm{Ag}^{+}$ions were converted to Ag NPs in the presence of oxalic acid and UV-Vis irradiation. ${ }^{21}$ The products were designated as $\mathrm{TiO}_{2}-\mathrm{Ag}-\mathrm{X}$, in which $\mathrm{X}$ indicates the contents of $\mathrm{Ag}$. The $X$ values in our experiments were 1.0, 2.0, 4.0, 6.0, 9.0, 15.0 and $20.0 \mathrm{wt} . \%$.

Samples consisting of $20 \mathrm{mg}$ of $\mathrm{TiO}_{2}-\mathrm{Ag}-\mathrm{X}$ were added to $100 \mathrm{~mL}$ of water and stirred for $20 \mathrm{~min}$. Next, $10 \mathrm{mg}$ of MWCNT were added and stirring continued for $30 \mathrm{~min}$. Isopropyl alcohol was then added in the concentration of $50 \mathrm{~mL}$ per $30 \mathrm{mg}$ of MWCNT followed by stirring for $30 \mathrm{~min}$, and ethylene glycol was dispersed at the concentration of $15 \mathrm{~mL}$ per $30 \mathrm{mg}$ of MWCNT. ${ }^{22,23}$ The resulting suspension remained under agitation for $6 \mathrm{~h}$ and was then filtered, washed with distilled water and the obtained solid $\left(\mathrm{MWCNT} / \mathrm{TiO}_{2}-\mathrm{Ag}-\mathrm{X}\right)$ was dried in an oven at $70{ }^{\circ} \mathrm{C}$. The $\mathrm{TiO}_{2}-\mathrm{Ag}$ in the catalyst was studied varying their quantity per $\mathrm{g}$ of MWCNT. The weight ratio of MWCNT:TiO ${ }_{2}$ - Ag was varied to $1: 1$, $1: 1.5,1: 2,1: 3$ and 1:4, and Ag wt.\% was maintained fixed at $9 \%$. The obtained catalysts were labeled as $\mathrm{Y}-\mathrm{MWCNT} / \mathrm{TiO}_{2}-\mathrm{Ag}$, where $\mathrm{Y}=11,11.5,12,13$ and 14 wt. ratio $\mathrm{MWCNT}: \mathrm{TiO}_{2}-\mathrm{Ag}$.

The $\mathrm{Fe} / \mathrm{MWCNT} / \mathrm{TiO}_{2}$-Ag composite was obtained by adding $1 \mathrm{~g}$ of 12-MWCNT/TiO $-\mathrm{Ag}-9$ to $500 \mathrm{~mL}$ of water. To this suspension, different amounts of iron oxide were added. The suspension was maintained under stirring for $2 \mathrm{~h}$, filtered, washed with distilled water and dried in an oven at $70{ }^{\circ} \mathrm{C}$. The magnetically recoverable catalysts were labeled as Z-Fe/MWCNT/TiO $-\mathrm{Ag}-9$, where $\mathrm{Z}=5.0,10.0$, 15.0, 20.0 and $25.0 \mathrm{wt} . \%$ of Fe.

\section{Photocatalyst characterization}

The determination of the final photocatalyst chemical compositions was made by mixing $0.100 \mathrm{~g}$ of each sample with $3 \mathrm{~mL}$ of $\mathrm{HNO}_{3}(65 \%), 4 \mathrm{~mL}$ of $\mathrm{H}_{2} \mathrm{SO}_{4}(96 \%), 4 \mathrm{~mL}$ of $\mathrm{HCl}(37 \%)$ and $1 \mathrm{~mL}$ of $\mathrm{HF}(40 \%)$, followed by digestion in an industrial microwave oven (Milestone Ethos) by heating to $230{ }^{\circ} \mathrm{C}$ for $15 \mathrm{~min}$ and maintaining this temperature for $20 \mathrm{~min}$ at 1,200 W. The digested samples were diluted and metal concentrations were determined by inductively 
coupled plasma mass spectrometry (ICP-MS), PerkinElmer model NexION 300D.

The textural properties of the samples were analyzed by their $\mathrm{N}_{2}$ adsorption-desorption isotherms using a surface area and pore size analyzer (NOVA 2200e Quanta Chrome Instruments, Boynton Beach, FL, USA). Prior to measurement, the samples were degassed at $110^{\circ} \mathrm{C}$ for $4 \mathrm{~h}$. Specific surface areas were estimated by the BrunauerEmmett-Teller (BET) method and pore volumes were determined by the Horváth-Kawasoe (HK) method applied to the desorption branch.

$\mathrm{X}$-ray diffraction (XRD) was measured by $2 \theta$ scans utilizing a Bruker model D8 Discover diffractometer using $\mathrm{Cu} K \alpha$ radiation $(\lambda=0.1541 \mathrm{~nm})$ with an angular variation of $5-80^{\circ}(2 \theta)$ and scan rate of 0.05 degree s$^{-1}$. The Powder Diffraction File (PDF) database (JCPDS, International Centre for Diffraction Data) was used to identify crystalline phases. Network parameters $\left(\mathrm{d}_{\mathrm{hk}}\right)$ of the composites were calculated according to the Bragg equation, $\lambda=2 \mathrm{~d} \operatorname{sen} \theta$, where $\lambda$ is the wavelength of $X$-rays $(\lambda=0.1541 \mathrm{~nm})$ and $\theta$ is the diffraction angle. ${ }^{24}$

Scanning electron microscopy (SEM) images were obtained using a JEOL JSM-6010/LA microscope. The SEM equipment was equipped with an energy dispersive spectrometry system (EDS) for analysis of the sample chemical composition.

Infrared spectra (IR) were obtained using a VARIAN 660-IR spectrophotometer equipped with an attenuated reflectance accessory PIKE Gladi ATR in the region of 400 to $4000 \mathrm{~cm}^{-1}$.

Diffuse reflectance spectra (DRS) were acquired on a dual-beam $20 \mathrm{GBC}$, Cintra model spectrophotometer, in the region of 350-700 $\mathrm{nm}$. Calcium carbonate was used as a non-absorbing standard.

Total organic carbon (TOC) was measured using a Shimadzu-5000A TOC analyzer.

In order to detect the presence of $\mathrm{TiO}_{2}$ and iron oxide in the catalysts, analyses were also conducted by Raman scattering, using a Renishaw Raman Invia micro spectrometer equipped with an argon laser $(514.5 \mathrm{~nm})$ with a $50 \times$ objective $(\mathrm{NA}=0.75$, corresponding to a spot of ca. $1 \mu \mathrm{m}$ in diameter) and spectral resolution of $1 \mathrm{~cm}^{-1}$.

The zeta potential of adsorbents was measured using the Zetasizer Nano ZS instrument at $\mathrm{pH}$ values from 2 to 8 .

\section{Photocatalytic activity}

The photocatalytic activity of the $\mathrm{Fe} / \mathrm{MWCNT} / \mathrm{TiO}_{2}-\mathrm{Ag}$ composites was assessed by photodegradation of a phenol solution in an annular photoreactor (Figure S1 in the Supplementary Information (SI) section). The composites and phenol solution were stirred for $15 \mathrm{~min}$ in the dark and then irradiated by UV-Vis light (filter cut off for $\lambda>300 \mathrm{~nm}$ ) for $180 \mathrm{~min}$. At established time intervals, aliquots were taken from samples, and filtered through a $0.45 \mu \mathrm{M}$ membrane (Millipore) for phenol and total organic carbon (TOC) quantification. The monitoring of the remaining phenol concentrations was carried out by high performance liquid chromatography (HPLC) using a 1260 Infinity system with a linear photodiode array detector (DAD) (Agilent Technologies). The chromatographic conditions used for quantification of phenol by HPLC-DAD are described by Almeida et al. ${ }^{25}$

Photolysis was evaluated under the same conditions without the presence of the catalyst and only UV-Vis light. All studies were performed in triplicate.

\section{Reuse assays}

Photocatalysts were washed with deionized water and dried before reuse. The photocatalysts were characterized by X-ray diffraction techniques and infrared spectroscopy before and after each photodegradation cycle to verify its stability.

\section{Results and Discussion}

Scanning electron microscopy, energy dispersive spectroscopy and chemical composition

Surface analysis of the materials by SEM is shown in Figure S2 (in the SI section). Figure S2a shows the carbon nanotubes. In Figures S2b and S2c, the presence of dispersed granules of $\mathrm{TiO}_{2}-\mathrm{Ag}$ and/or iron oxide along the surface of the carbon nanotubes is observed. ${ }^{26,27}$ The image of the material after ten consecutive reutilization cycles (Figure S2d) presents morphology similar to that of the unused material, thus confirming maintenance of the material structure. Figure S3 (in the SI section) shows the elemental analysis results of EDS spectra. The presences of Ti, Ag and Fe peaks are observed in the spectra. The spectrum of Figure S3d is similar to that of Figure S3c, indicating that the structure of the catalyst was not altered after ten reuse cycles.

Table 1 shows the quantities determined by ICP-MS of the $\mathrm{Ti}, \mathrm{Ag}$ and $\mathrm{Fe}$ metals in the composites making up the catalysts. It can be observed that the quantities of each metal in the catalyst were close to the values initially calculated.

\section{Specific surface area}

The pore surface area and pore volume of the (Table 1) MWCNT/TiO 2 -Ag-9 and 10-Fe/MWCNT/TiO 2 -Ag-9 
Table 1. Initial and final chemical compositions, final mass ratios, band-gap values and textural analysis of the synthesized photocatalysts

\begin{tabular}{|c|c|c|c|c|c|c|c|c|c|c|c|c|c|}
\hline \multirow{3}{*}{ Sample } & \multicolumn{6}{|c|}{ Ratio (wt.) } & \multicolumn{4}{|c|}{ Metal loading / wt. $\%$} & \multirow{3}{*}{$\begin{array}{c}\text { Band gap / } \\
\text { eV }\end{array}$} & \multirow{3}{*}{$\begin{array}{c}\mathrm{S}_{\mathrm{BET}^{\mathrm{a}}} / \\
\left(\mathrm{m}^{2} \mathrm{~g}^{-1}\right)\end{array}$} & \multirow{3}{*}{$\begin{array}{l}\text { Pore volume / } \\
\qquad\left(\mathrm{cm}^{3} \mathrm{~g}^{-1}\right)\end{array}$} \\
\hline & \multicolumn{3}{|c|}{ Initial } & \multicolumn{3}{|c|}{ Final } & \multicolumn{2}{|c|}{ Initial } & \multicolumn{2}{|c|}{ Final } & & & \\
\hline & $\mathrm{Ag}: \mathrm{Ti}$ & Fe:Ti & $\mathrm{Fe}: \mathrm{Ag}: \mathrm{Ti}$ & $\mathrm{Ag}: \mathrm{Ti}$ & $\mathrm{Fe}: \mathrm{Ti}$ & Fe:Ag:Ti & $\mathrm{Ag}$ & $\mathrm{Fe}$ & $\mathrm{Ag}$ & $\mathrm{Fe}$ & & & \\
\hline MWCNT & - & - & - & - & - & - & - & - & - & - & - & 95.5 & 0.0344 \\
\hline $\mathrm{TiO}_{2}$ & - & - & - & - & - & - & - & - & - & - & 3.20 & 48.0 & 0.0178 \\
\hline $\mathrm{TiO}_{2}-\mathrm{Ag}-9$ & $1: 7$ & - & - & $1: 6.9$ & - & - & 9.0 & - & 8.4 & - & 3.05 & 55.7 & 0.0203 \\
\hline MWCNT/TiO 2 -Ag-9 & $1: 7$ & - & - & $1: 6.8$ & - & - & 9.0 & - & 8.2 & - & 2.84 & 64.7 & 0.0235 \\
\hline 10-Fe/MWCNT/TiO 2 & $1: 7$ & $1: 6$ & - & - & $1: 6$ & - & - & 10 & - & 9.5 & 2.52 & 60.7 & 0.0223 \\
\hline 10-Fe/MWCNT/TiO $2-A g-9$ & $1: 7$ & $1: 6$ & $1: 1.2: 7$ & $1: 6.9$ & $1: 5.8$ & $1: 1.1: 6.9$ & 9.0 & 10 & 8.6 & 9.8 & 2.24 & 68.8 & 0.0253 \\
\hline
\end{tabular}

${ }^{\mathrm{a}} \mathrm{S}_{\mathrm{BET}}$ : specific surface area.

catalysts are greater than those of $\mathrm{TiO}_{2}$ and $\mathrm{TiO}_{2}-\mathrm{Ag}-9$. The introduction of MWCNT in the catalysts prevents the $\mathrm{TiO}_{2}$ particle agglomerations, increasing the surface area. ${ }^{28}$ The SEM images reinforce this fact, showing that the $\mathrm{TiO}_{2}-\mathrm{Ag}$ and/or iron oxide particles were dispersed on the surface of MWCNTs.

\section{X-ray diffraction}

The diffractograms obtained for the X-ray diffraction patterns of the samples are shown in Figure 1. The peaks corresponding to the carbon nanotubes (Figure 1a) appear at $26.10^{\circ}$ and $44.70^{\circ}$, and correspond to the diffraction planes (002) and (100). ${ }^{28,29}$ Regarding the diffractogram of iron oxide (Figure 1b), characteristic peaks of magnetite and maghemite are observed, being indistinguishable by XRD. ${ }^{30}$ The main peaks of magnetite-maghemite were observed at $30.10^{\circ}, 35.50^{\circ}, 43.10^{\circ}, 53.40^{\circ}, 57.04^{\circ}$ and $62.88^{\circ}$, representing the diffraction planes (220), (311), (400), (422), (511) and (440), respectively. ${ }^{31-33}$ The diffractogram in Figure 1c shows the main peaks for $\mathrm{TiO}_{2}$. The peaks are labeled A (hkl) or $\mathrm{R}(\mathrm{hkl})$ related to the anatase (JCPDS file No. 21-1272) or rutile (JCPDS file No. 21-1276) phases, respectively, and agree with the crystallographic standards found in the literature. ${ }^{34-36}$ The X-ray diffraction patterns of $\mathrm{TiO}_{2}-\mathrm{Ag}$ (Figure 1d) exhibit characteristic peaks of metallic silver $\left(\mathrm{Ag}^{0}\right)$. However, the largest peak that reveals the crystalline structure of silver appears at $38.20^{\circ}$ referring to the plane (111) superimposed on the peak $37.80^{\circ}(004)$ of the $\mathrm{TiO}_{2}$ anatase phase. ${ }^{37}$ Silver $\left(\mathrm{Ag}^{+}\right)$has an ionic ratio of $0.126 \mathrm{~nm}$, greater than $\mathrm{Ti}^{4+}(0.068 \mathrm{~nm})$, making impossible its substitution in the crystalline structure of $\mathrm{TiO}_{2}$, but permitting only the impregnation on the $\mathrm{TiO}_{2}$ surface. ${ }^{38}$

The diffractogram of $10-\mathrm{Fe} / \mathrm{MWCNT} / \mathrm{TiO}_{2}-\mathrm{Ag}-9$ is not altered when compared to the precursors, MWCNT, iron oxide and nano- $\mathrm{TiO}_{2}$. There was only the overlapping of

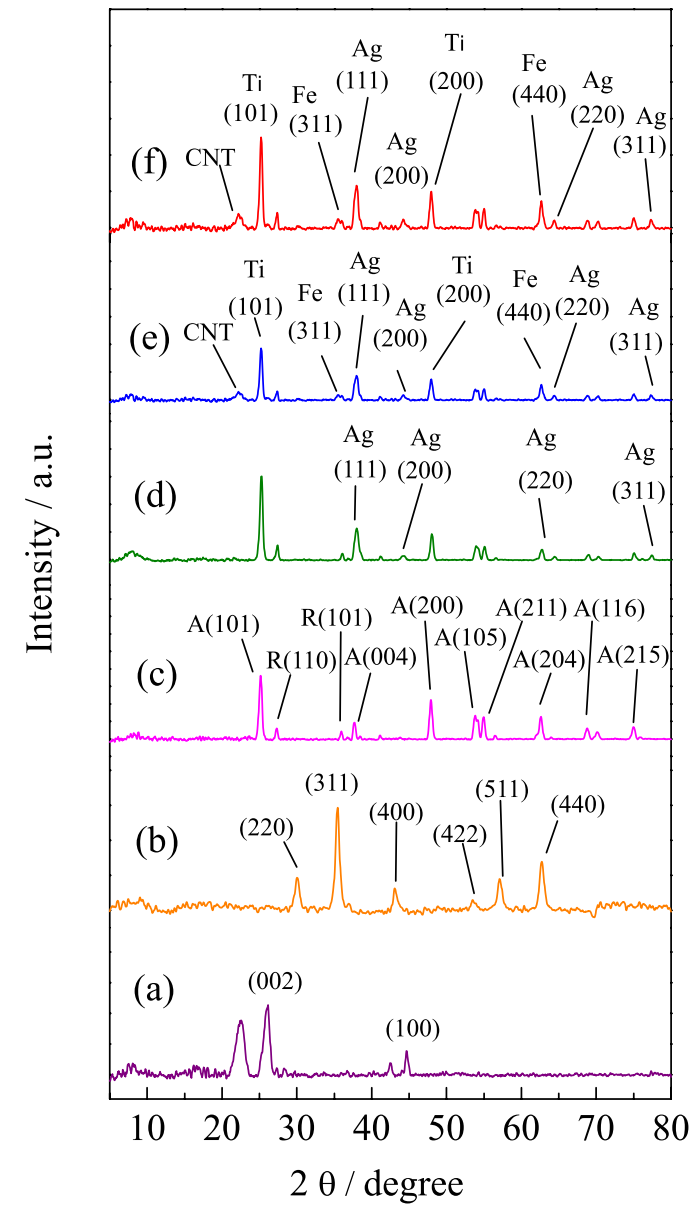

Figure 1. X-ray diffraction patterns of (a) MWCNT, (b) magnetic iron oxide, (c) $\mathrm{TiO}_{2}$, (d) $\mathrm{TiO}_{2}-\mathrm{Ag}-9$, (e) 10-Fe/MWCNT/TiO $2-\mathrm{Ag}-9$ and (f) $10-\mathrm{Fe} / \mathrm{MWCNT} / \mathrm{TiO}_{2}-\mathrm{Ag}-9$ (reused).

the peaks, and this demonstrates that the combination of iron oxide, $\mathrm{TiO}_{2}$ and MWCNT is likely a physical process.

\section{Infrared spectroscopy analysis}

Figure $2 \mathrm{a}$ shows the obtained spectrum for $\mathrm{TiO}_{2}$ nanoparticles, in which there is an absorption band in the 
low frequency region $\left(400-800 \mathrm{~cm}^{-1}\right)$, which is associated to the Ti-O vibration mode from the structure of $\mathrm{Ti}-\mathrm{O}-\mathrm{Ti}$ bonds. The spectrum obtained for the carbon nanotubes (Figure $2 \mathrm{~b}$ ) shows the presence of $\mathrm{C}=\mathrm{C}$ stretching bands at $1580 \mathrm{~cm}^{-1}$ and $\mathrm{C}-\mathrm{C}$ at $2340 \mathrm{~cm}^{-1} .39,40$

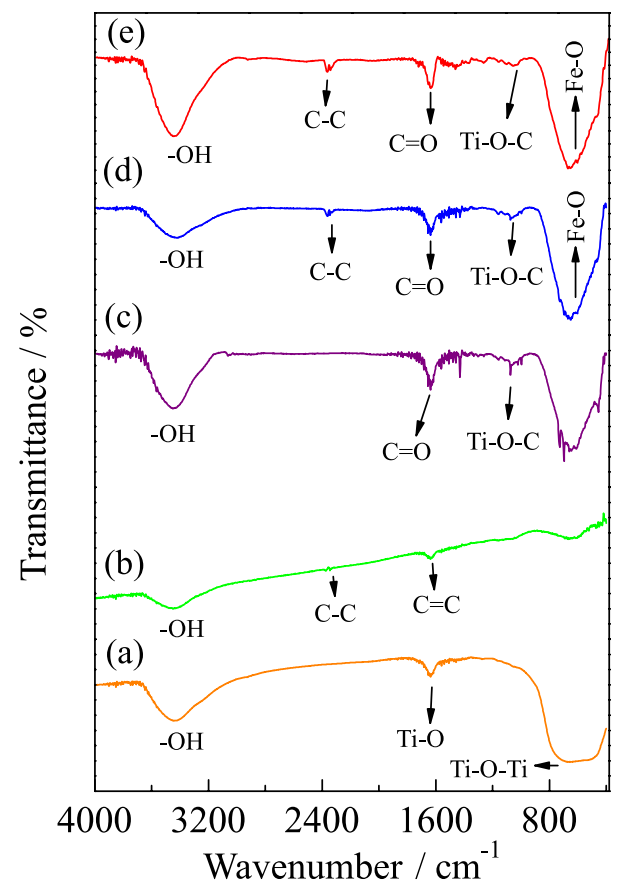

Figure 2. Infrared spectra of (a) $\mathrm{TiO}_{2}$, (b) MWCNT, (c) MWCNT/TiO 2 -Ag-9, (d) $10-\mathrm{Fe} / \mathrm{MWCNT} / \mathrm{TiO}_{2}-\mathrm{Ag}-9$ and (e) $10-\mathrm{Fe} / \mathrm{MWCNT} / \mathrm{TiO}_{2}-\mathrm{Ag}-9$ (reused).

The spectra of Figures $2 \mathrm{~d}$ and 2e show the presence of bands at 572 and $628 \mathrm{~cm}^{-1}$ characteristic of the $\mathrm{Fe}-\mathrm{O}$ bond of the magnetic iron oxide. ${ }^{41}$ In the spectra of Figures 2c-2e, a stretching of the Ti-O-C bond at $1065 \mathrm{~cm}^{-1}$ is observed, confirming the bond of $\mathrm{TiO}_{2}$ to the carbon nanotube structures. ${ }^{42}$

\section{Raman spectroscopy}

Figure 3 shows the Raman spectrum of the synthesized catalysts. The Raman spectrum of iron oxide (Figure 3a) shows a broad band from $670-720 \mathrm{~cm}^{-1}$ associated to magnetite and maghemite phases. ${ }^{43}$ The bands in the range of $1370-1580 \mathrm{~cm}^{-1}$ are related to the magnetic properties of the iron oxide crystals, which may indicate the presence of maghemite since they are not encountered in the pure magnetite samples. ${ }^{43,44}$ The spectrum of the carbon nanotubes (Figure $3 b$ ) shows two characteristic bands, the $G$ band located at $1580 \mathrm{~cm}^{-1}$ corresponding to the $\mathrm{sp}^{2}$ bonds of the crystalline graphitic sheets, and the D band at $1354 \mathrm{~cm}^{-1}$ corresponding to defects of $\mathrm{sp}^{3}$ bonds in the pentagonal and heptagonal carbon structures of the nanotubes. ${ }^{45} \mathrm{The}^{\mathrm{TiO}_{2}}$ spectrum (Figure 3c) shows four characteristic bands of the anatase and rutile phases of $\mathrm{TiO}_{2}$. The bands at 137, 387, 513 and $638 \mathrm{~cm}^{-1}$ correspond to the anatase phase and at $440 \mathrm{~cm}^{-1}$ to the rutile phase. ${ }^{45,46} \mathrm{The}_{\mathrm{TiO}}-\mathrm{Ag}-9$ composite (Figure 3d) presented a new band at $90 \mathrm{~cm}^{-1}$ corresponding to the vibration mode of the Ag structure, moreover the band of $\mathrm{TiO}_{2}$ at $137 \mathrm{~cm}^{-1}$ was shifted to $145 \mathrm{~cm}^{-1}$ due to the resonant Raman effect caused by deposition of Ag NPs on the $\mathrm{TiO}_{2}{ }^{47}$ The phonon confinement can cause these changes to the Raman vibration mode and peak intensities. ${ }^{37}$ Spectra of the MWCNT/TiO ${ }_{2}$-Ag-9 and $10-\mathrm{Fe} / \mathrm{MWCNT} / \mathrm{TiO}_{2}$-Ag-9 composites are shown in Figures $3 \mathrm{e}$ and $3 \mathrm{f}$. These spectra indicated the shift in wavenumbers and intensities of the $\mathrm{D}$ and $\mathrm{G}$ bands of the MWCNT from interaction with $\mathrm{TiO}_{2}-\mathrm{Ag}$ and the iron oxide.

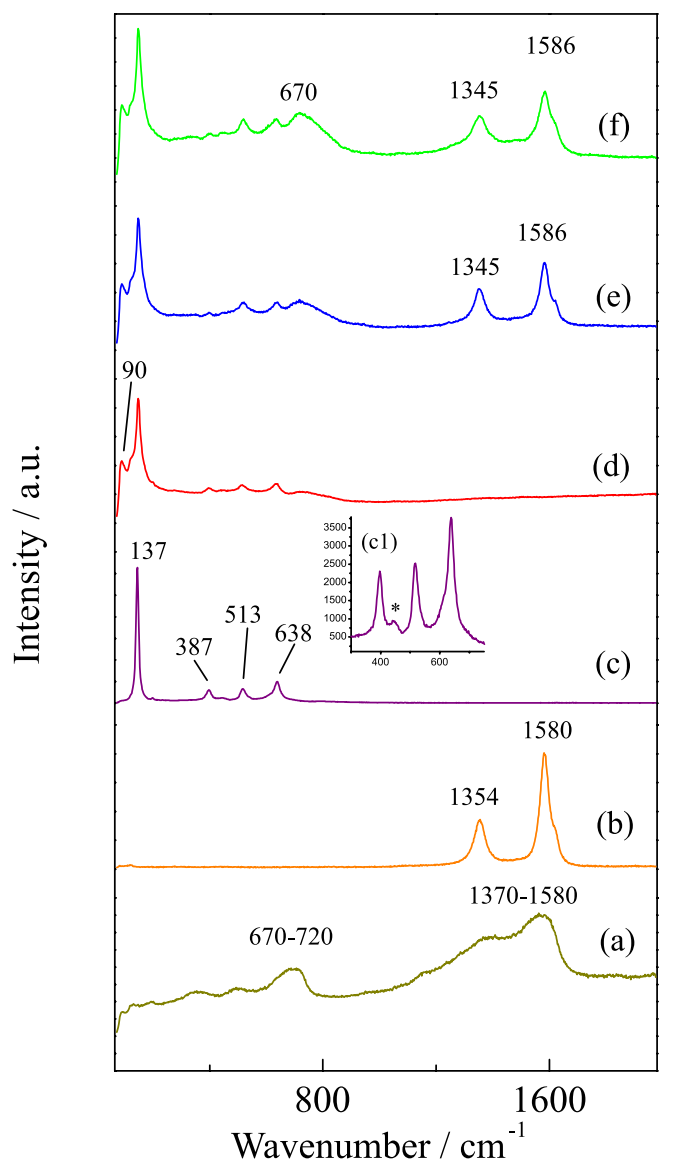

Figure 3. Raman spectra of (a) iron oxide, (b) MWCNT, (c) $\mathrm{TiO}_{2},\left(c_{1}\right)$ expanded spectrum for $\mathrm{TiO}_{2}$ range $300-750 \mathrm{~cm}^{-1}$ (*rutile phase of $\mathrm{TiO}_{2}$ ), (d) $\mathrm{TiO}_{2}-\mathrm{Ag}-9$, (e) MWCNT/TiO $-\mathrm{Ag}-9$ and (f) $10-\mathrm{Fe} / \mathrm{MWCNT} / \mathrm{TiO}_{2}-\mathrm{Ag}-9$.

The $\mathrm{G}$ band of carbon nanotubes showed a shift of $6 \mathrm{~cm}^{-1}$ to blue and the D band of $9 \mathrm{~cm}^{-1}$ to red due to adhesion of the $\mathrm{TiO}_{2}-\mathrm{Ag}$ on the surface of the carbon nanotubes..$^{37}$ The intensity ratio of the $\mathrm{D}$ and $\mathrm{G}$ bands of carbon nanotubes was ID/IG $=0.4251$, for the composite 
MWCNT/TiO 2 -Ag-9 ID/IG $=0.7283$ and for the composite 10-Fe/MWCNT/TiO 2 -Ag-9 ID/IG = 0.6989. The increase of the intensity ratio is due to disturbances in the structure of the nanotubes by interaction with the $\mathrm{TiO}_{2}-\mathrm{Ag}$ and iron oxide nanoparticles. ${ }^{48}$ The presence of the $\mathrm{TiO}_{2}-\mathrm{Ag}$ bands of the magnetite-maghemite and the shifts of the $\mathrm{D}$ and $\mathrm{G}$ bands of the carbon nanotubes (Figure 3f) indicated that there was a strong interaction between the catalyst components.

\section{Determination of band-gap values}

Figures $4 \mathrm{a}$ and $4 \mathrm{~b}$ show the UV-Vis spectra of diffuse reflectance. The Kubelka-Munk function $\mathrm{F}(\mathrm{R})=(1-\mathrm{R})^{2} / 2 \mathrm{R}(\mathrm{R}$ is the reflectance) was used to calculate the band-gap energy of the catalysts. ${ }^{49}$ The calculation of the band-gap energy (Figure $4 \mathrm{~b}$ ) was performed by extrapolating the line obtained in the regression of the linear portion of $[\mathrm{F}(\mathrm{R}) \mathrm{hv}]^{\mathrm{n}}(\mathrm{n}=1 / 2$ for indirect gap) vs. energy (hv), where $\mathrm{h}$ is Planck's constant and $v$ the frequency of light. ${ }^{50}$ The band-gap values for $\mathrm{TiO}_{2}, \mathrm{TiO}_{2}-\mathrm{Ag}-9$, MWCNT/TiO $2-A g-9$, 10-Fe/MWCNT/TiO $2,10-\mathrm{Fe} / \mathrm{MWCN}_{2} / \mathrm{TiO}_{2}-\mathrm{Ag}-9$ and iron oxide are 3.20, 3.05, 2.84, 2.52, 2.24 and $1.97 \mathrm{eV}$, respectively. The $10-\mathrm{Fe} / \mathrm{MWCNT} / \mathrm{TiO}_{2}-\mathrm{Ag}-9$ catalyst showed light absorption shifted to the visible region. This shift is due to the electronic interaction of molecular orbitals between iron oxide (presenting a narrow band gap, $0.1 \mathrm{eV}$ for magnetite and $2.2 \mathrm{eV}$ for maghemite) and $\mathrm{TiO}_{2}$ (3.2-3.3 eV), constructing a new molecular orbital and reducing the band difference. Similar phenomena were observed between graphene and $\mathrm{TiO}_{2},{ }^{51}$ carbon nanotubes and $\mathrm{TiO}_{2},{ }^{52}$ and $\mathrm{TiO}_{2}$ and iron oxide. ${ }^{53}$ The displacement of radiation absorption to the visible region is also due to MWCNTs which act as photogenerated electron acceptors and to the surface plasmon resonance of electrons present in the $\mathrm{Ag}^{0}$ nanoparticles. ${ }^{37,54}$

Thus, the combination of iron oxide, $\mathrm{Ag}^{0}$ and MWCNT in the catalyst composition contributed to increase the absorption of the visible light by $\mathrm{TiO}_{2}$. The photogenerated electrons in the conduction band and the valence band gaps of the $\mathrm{TiO}_{2}$ may be trapped by the iron oxide, maintaining the electron-hole separation. ${ }^{55}$ In the charge transfer process, the $\mathrm{Fe}^{3+}$ of iron oxide is reduced to $\mathrm{Fe}^{2+}$ by the electrons of the $\mathrm{TiO}_{2}$ conduction band, the $\mathrm{Fe}^{2+}$ can be oxidized to $\mathrm{Fe}^{3+}$ and the generated electrons react with $\mathrm{O}_{2}$ to produce the superoxide ion $\left(\mathrm{O}_{2}{ }^{--}\right) .^{55-58} \mathrm{The} \mathrm{Fe}^{3+}$ of iron oxide can be oxidized by the $\mathrm{TiO}_{2}$ valence band gap to form $\mathrm{Fe}^{4+}$ which reacts with ${ }^{-} \mathrm{OH}$ ions to form ${ }^{\circ} \mathrm{OH}$ radicals. ${ }^{56}$ Electron transfer may also occur directly from the $\mathrm{TiO}_{2}$ conduction band to the $\mathrm{Ag}$ NPs. The $\mathrm{Ag}^{0}$ which has a higher working
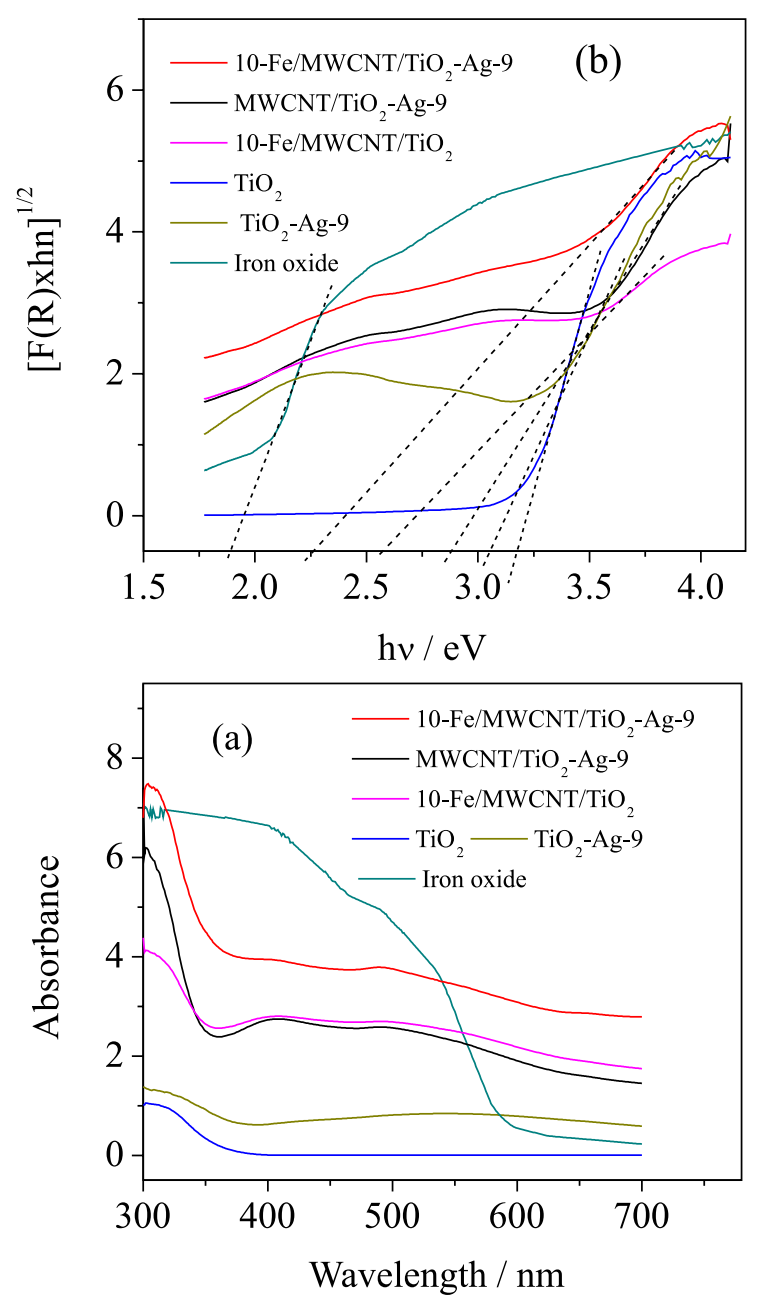

Figure 4. (a) UV-Vis absorption spectrum of the photocatalysts and (b) determination of band-gap values $(\mathrm{Eg})$ for the photocatalysts.

function $(4.26 \mathrm{eV})$ than that of $\mathrm{TiO}_{2}(4.20 \mathrm{eV})$ can capture photogenerated electrons on $\mathrm{TiO}_{2}$ and transfer them to MWCNTs, and these electrons can react with $\mathrm{O}_{2}$ to form the radical $\mathrm{O}_{2} \cdot-.58,59$ Thus, the effect of the interaction between the components of the catalyst increases the transport of electrons, prevents the recombination of charges and allows the use of visible radiation in the photodegradation of phenol.

\section{Photocatalytic activity and kinetics}

Figure 5 shows the results obtained in the phenol oxidation by varying the amounts of $\mathrm{Ti}, \mathrm{Ag}$ and $\mathrm{Fe}$ added to the catalyst. In Figure 5a, it was verified that the photocatalyst which promoted the highest removal of phenol was that with a MWCNT: $\mathrm{TiO}_{2}-\mathrm{Ag}$ ratio of 1:2 (12-MWCNT/TiO $\left.{ }_{2}-\mathrm{Ag}\right)$. Figure $5 \mathrm{~b}$ shows that the maximum photodegradation efficiency was obtained by the catalyst with 9 wt. $\% \mathrm{Ag}\left(0.000834 \mathrm{~mol} \mathrm{~g}^{-1}\right)$. The increase in wt.\% of Ag improves the efficiency of the catalyst, but when reaching a silver content ( $>9 \%$ ), the opposite effect 
occurred. The Ag nanoparticles increase the probability of electron capture by the valence band of $\mathrm{TiO}_{2}$, reducing the charge separation time and hence the photocatalytic efficiency. ${ }^{7}$ In Figure $5 c$, the highest photocatalytic efficiency was obtained by the catalyst with $10 \mathrm{wt} . \% \mathrm{Fe}$ $\left(0.0018 \mathrm{~mol} \mathrm{~g}^{-1}\right)$. For larger amounts of Fe, the efficiency decreases. Larger quantities of $\mathrm{Fe}^{3+}$ decrease the surface area of the catalyst to prevent light penetration. ${ }^{60,61}$

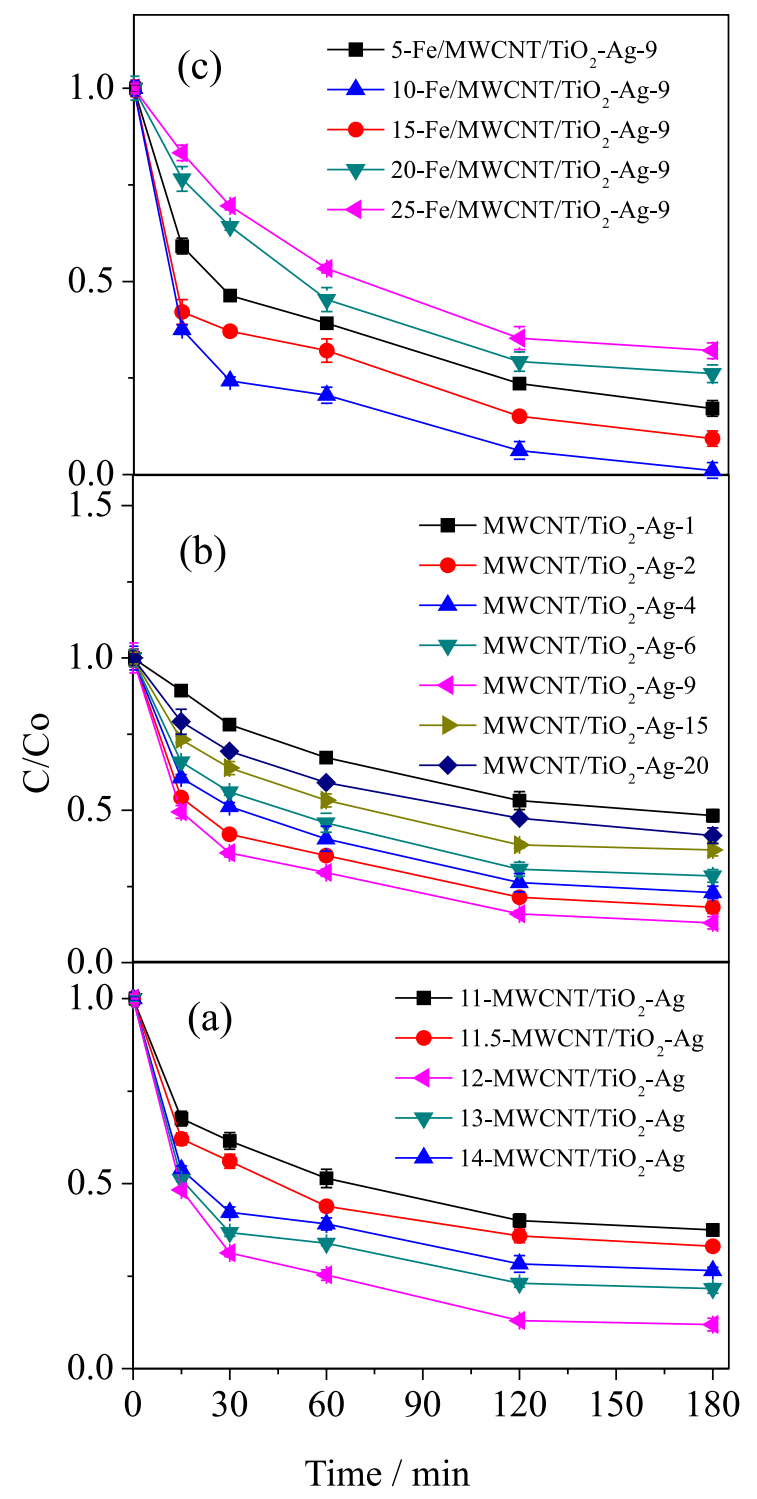

Figure 5. Photocatalytic activity of the catalysts: (a) with different amounts of $\mathrm{TiO}_{2}-\mathrm{Ag}$, (b) with different amounts of $\mathrm{Ag}$ and (c) with different amounts of iron oxide for phenol degradation. Reaction conditions: initial phenol concentration of $50 \mathrm{mg} \mathrm{L}^{-1}, 300 \mathrm{mg}$ of photocatalyst, reaction temperature $30 \pm 2{ }^{\circ} \mathrm{C}$ and initial $\mathrm{pH}$ 5.2.

Figure 6 shows the influence of $\mathrm{pH}$ on phenol photodegradation by $10-\mathrm{Fe} / \mathrm{MWCNT} / \mathrm{TiO}_{2}-\mathrm{Ag}-9$ and determination of the point of zero charge (ZPC) for the catalysts. The $\mathrm{ZPC}$ values determined for $\mathrm{TiO}_{2}$ and
MWCNT were 6.10 and 4.00, respectively, and are in agreement with values reported in the literature. ${ }^{4,62}$ The $\mathrm{ZPC}$ value of the $10-\mathrm{Fe} / \mathrm{MWCNT} / \mathrm{TiO}_{2}-\mathrm{Ag}-9$ catalyst was 5.49 (Figure 6a), being that at values of $\mathrm{pH}<\mathrm{pH}_{\mathrm{ZPC}}$, the catalyst surface is positively charged, and at $\mathrm{pH}>\mathrm{pH}_{\mathrm{ZPC}}$, it is negatively charged. Figure $6 \mathrm{~b}$ shows that the removal of phenol by the catalyst was highest in the $\mathrm{pH}$ range of 3.0 to $5.20\left(\mathrm{pH}<\mathrm{pH}_{\mathrm{ZPC}}\right)$, and at $\mathrm{pH}>\mathrm{pH}_{\mathrm{ZPC}}$, there was a decrease in the removal of phenol.
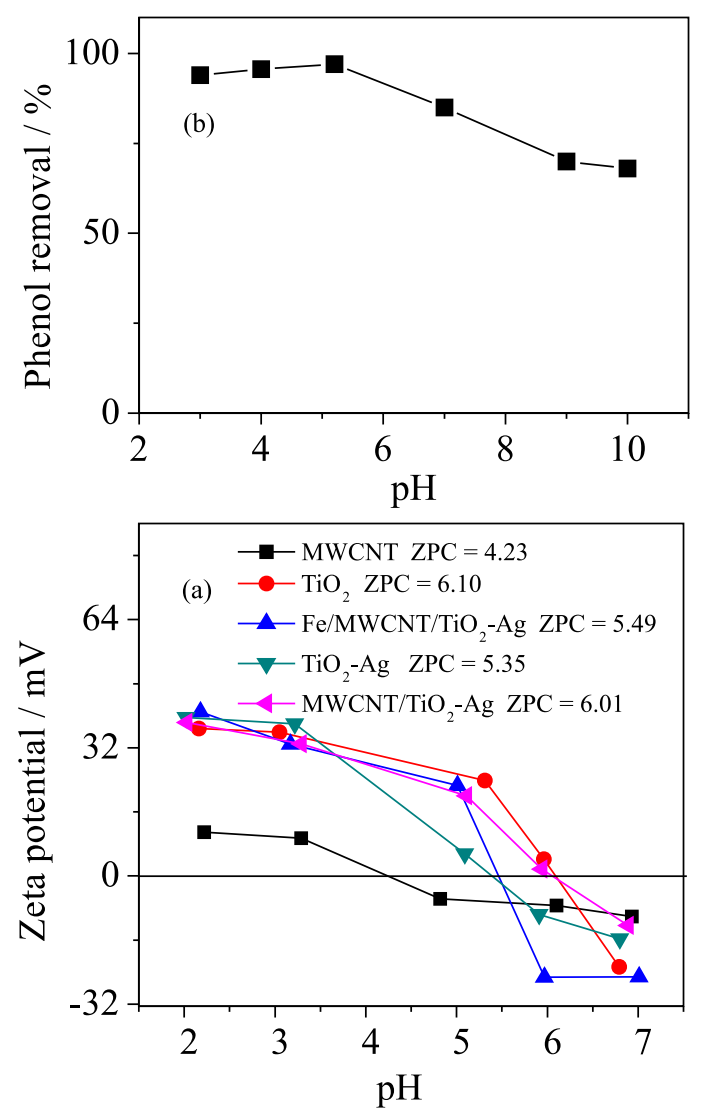

Figure 6. (a) Zeta potential measurements, (b) influence of $\mathrm{pH}$ on the removal of phenol by the catalyst $10-\mathrm{Fe} / \mathrm{MWCNT}-\mathrm{TiO}_{2}-\mathrm{Ag}-9$. Reaction conditions: initial phenol concentration of $50 \mathrm{mg} \mathrm{L}^{-1}, 300 \mathrm{mg}$ of photocatalyst and reaction temperature $30 \pm 2{ }^{\circ} \mathrm{C}$.

At $\mathrm{pH}$ of 3.0 to $5.20\left(\mathrm{pH}<\mathrm{pH}_{\mathrm{ZPC}}\right)$, the catalyst surface is positively charged and the electron recombination rate with $\mathrm{h}_{\mathrm{VB}}{ }^{+}$holes is minimized by providing a greater photocatalytic activity. The presence of negative charges on the catalyst surface $\left(\mathrm{pH}>\mathrm{pH}_{\mathrm{ZPC}}\right)$ inhibits the adsorption of ${ }^{-} \mathrm{OH}$ ions and water molecules, and consequently decreases the amount of ${ }^{\circ} \mathrm{OH}$ radicals formed, in addition to increasing the recombination rate of the electrons generated in the conduction band with valence band of $\mathrm{TiO}_{2}{ }^{18} \mathrm{At}$ $\mathrm{pH}$ above 9, carbonate is found in solution (formed by the absorption of $\mathrm{CO}_{2}$ from the air), and reacts with ${ }^{-} \mathrm{OH}$ ions to diminish the production of ${ }^{\circ} \mathrm{OH}$ radicals, reducing the 
removal of phenol. ${ }^{63}$ Phenol $(\mathrm{pKa}=9.95)$ at $\mathrm{pH} 9-10$ is found in the form of phenoxide ion, which is repelled by the negative loads on the surface of the catalyst $\left(\mathrm{pH}>\mathrm{pH}_{\mathrm{ZPC}}\right)$, contributing to the decrease of the phenol removal rate. ${ }^{64}$

A comparison of the various synthesized catalysts (Figure 7) shows a high efficiency for phenol photodegradation by $10-\mathrm{Fe} / \mathrm{MWCNT}_{\mathrm{TiO}}-\mathrm{Ag}-9$ (ca. 100\%). In studies on the absence of radiation, the phenol removal was assessed by adsorption.

InFigure $7 \mathrm{a}$, it is observed that $10-\mathrm{Fe} / \mathrm{MWCNT}_{\mathrm{TiO}}-\mathrm{Ag}-9$ adsorbed $7 \%$ of phenol after $180 \mathrm{~min}$ in the absence of UV-Vis radiation. The TOC removal was also quantified (Figure 7b) to measure the degree of phenol mineralization.

The catalyst $10-\mathrm{Fe} / \mathrm{MWCNT} / \mathrm{TiO}_{2}-\mathrm{Ag}-9$, which resulted in the highest phenol removal (Figure 7a), also generated a greater reduction in TOC, reaching approximately $85 \%$ after $180 \mathrm{~min}$. The $\mathrm{TiO}_{2}$ catalyst when compared to $\mathrm{TiO}_{2}-\mathrm{Ag}-9$ generated an increase in the phenol photodegradation by 28 to $68 \%$. The incorporation of Ag NPs in the 10-Fe/MWCNT-TiO 2 forming the 10-Fe/MWCNT/TiO 2 - Ag-9 catalyst had an additive effect, increasing the amount of phenol removed from 79 to ca. $100 \%$, respectively.

The schemes of photoactivation of the catalyst and phenol degradation are shown in Figure 8. One photon (hv) with energy greater than the band-gap energy of $\mathrm{TiO}_{2}$ promotes the valence band electrons (VB) to the conduction band. ${ }^{65} \mathrm{Ag}$ NPs in contact with $\mathrm{TiO}_{2}$ captured the photogenerated electrons $\left(\mathrm{e}_{\mathrm{CB}}^{-}\right)$, increasing the electron-hole separation and preventing recombination..$^{55}$

The process of transferring electrons $\left(\mathrm{e}_{\mathrm{CB}}^{-}\right)$from $\mathrm{TiO}_{2}$ to Ag NPs (equations 1 and 2) occurs spontaneously due to its Fermi level being greater than that of Ag NPs. ${ }^{66}$ Electrons stored in Ag NPs are transferred to MWCNT, which acts as donors of these electrons to dissolved oxygen to form the radical ion superoxide $\left(\mathrm{O}_{2}^{\cdot-}\right)$ (equation 3$)$. This transforms into reactive oxygen species, such as ${ }^{\circ} \mathrm{OH}, \mathrm{HO}_{2}{ }^{\bullet}$ and $\mathrm{H}_{2} \mathrm{O}_{2}{ }^{.8}$

$$
\begin{aligned}
& \mathrm{TiO}_{2}+\mathrm{h} v \rightarrow \mathrm{e}_{\mathrm{BC}}^{-}+h_{V B}^{+} \\
& \mathrm{e}_{\mathrm{CB}}^{-}+(\mathrm{Ag}) \rightarrow \mathrm{e}^{-}(\mathrm{Ag}) \\
& (\mathrm{MWCNT}) \mathrm{e}^{-}+\mathrm{O}_{2} \rightarrow \mathrm{MWCNT}+\mathrm{O}_{2}^{--}
\end{aligned}
$$

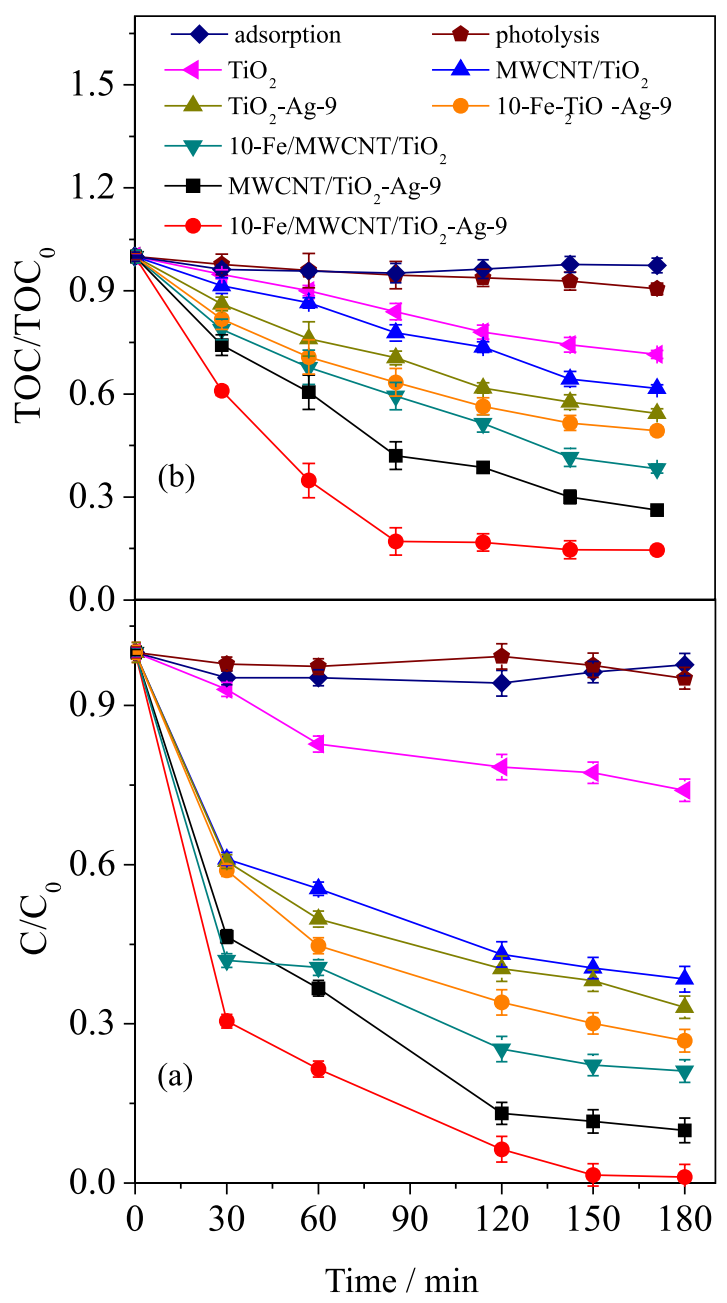

Figure 7. (a) Comparison of the photocatalytic activity of the catalysts for the removal of phenol, (b) variation in the total organic carbon content (TOC) of the solution during the phenol photodegradation. Reaction conditions: initial phenol concentration of $50 \mathrm{mg} \mathrm{L}^{-1}, 300 \mathrm{mg}$ of photocatalyst, reaction temperature $30 \pm 2{ }^{\circ} \mathrm{C}$ and initial $\mathrm{pH}$ 5.2.

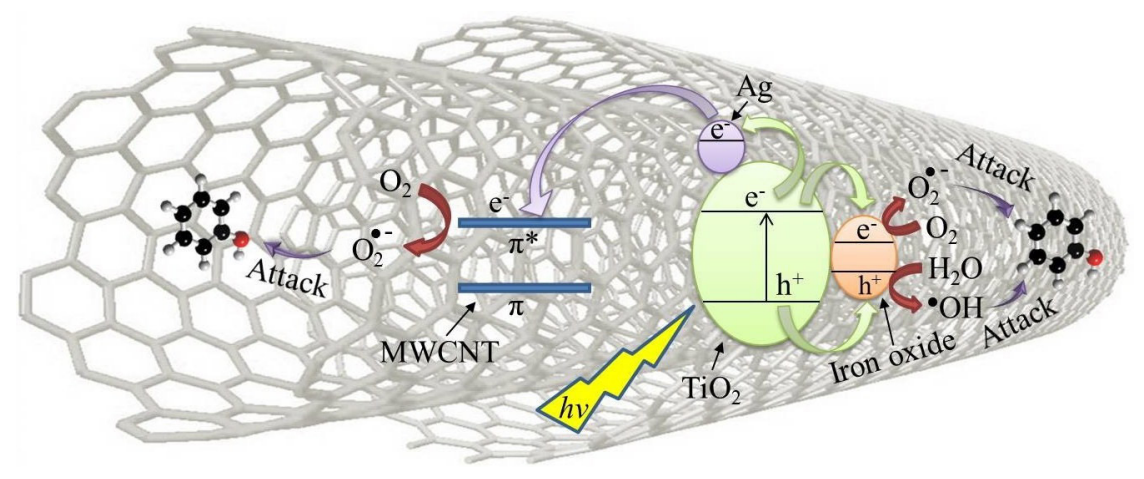

Figure 8. Proposal of the photocatalytic activation mechanism and phenol degradation. 
The iron oxide present in the catalyst can act as a temporary site for capture of electrons $\left(\mathrm{e}_{\mathrm{CB}}^{-}\right)$and holes $\left(\mathrm{h}^{+}{ }_{\mathrm{VB}}\right)$ photogenerated on $\mathrm{TiO}_{2}{ }^{55,67}$ Thus, the $\mathrm{Fe}^{3+}$ from iron oxide may act as a temporary photogenerator of electrons (equation 4) or in the capture of photogenerated electrons (equation 5), inhibiting the charge recombination of the $\mathrm{TiO}_{2}{ }^{67}$

$$
\begin{aligned}
& \mathrm{Fe}^{3+}+\mathrm{h}_{\mathrm{VB}}^{+} \rightarrow \mathrm{Fe}^{4+}+\mathrm{e}^{-} \\
& \mathrm{Fe}^{3+}+\mathrm{e}_{\mathrm{CB}}^{-} \rightarrow \mathrm{Fe}^{2+}
\end{aligned}
$$

Because $\mathrm{Fe}^{2+}$ and $\mathrm{Fe}^{4+}$ are more unstable than $\mathrm{Fe}^{3+}$, there is a strong tendency for charge transfer of the $\mathrm{TiO}_{2}$ surface to the iron oxide, forming the hydroxyl and superoxide radicals (equations 6 and 7). ${ }^{55,62,68}$

$\mathrm{Fe}^{2+}+\mathrm{O}_{2} \rightarrow \mathrm{Fe}^{3+}+\mathrm{O}_{2}^{--}$

$\mathrm{Fe}^{4+}+\left(\mathrm{H}_{2} \mathrm{O} \rightleftarrows \mathrm{H}^{+}+{ }^{-} \mathrm{OH}\right)_{\mathrm{ads}} \rightarrow \mathrm{Fe}^{3+}+{ }^{\cdot} \mathrm{OH}$

The hydroxyl radicals and the superoxide anion produced in this process have sufficient oxidative potential to degrade phenol molecules (equations 8 and 9).

$\mathrm{O}_{2}^{--}+$phenol $\rightarrow$ degradation of phenol

$\cdot \mathrm{OH}+$ phenol $\rightarrow$ degradation of phenol

Table S1 (in the SI section) presents a summary of photocatalytic phenol degradation studies published in the literature. It can be observed that phenol degradation by 10-Fe/MWCNT/TiO 2 -Ag-9 showed satisfactory performance compared to other catalysts previously reported.

\section{Kinetics of phenol photodegradation}

The photocatalytic reactions by degradation of organic pollutants follow pseudo-first-order model of LangmuirHinshelwood shown in equation $10 .^{69,70}$

$\mathrm{r}=-\frac{\mathrm{dC}}{\mathrm{dt}}=\frac{\mathrm{k}_{\mathrm{r}} \mathrm{K}_{\mathrm{ad}} \mathrm{C}}{1+\mathrm{K}_{\mathrm{ad}} \mathrm{C}}$

where $r$ is degradation rate $\left(\mathrm{mg} \mathrm{L}^{-1} \mathrm{~min}^{-1}\right), \mathrm{t}$ the reaction time ( $\mathrm{min}), \mathrm{C}$ the concentration of the organic compound $\left(\mathrm{mg} \mathrm{L}^{-1}\right), \mathrm{k}_{\mathrm{r}}$ the intrinsic rate constant and $\mathrm{K}_{\mathrm{ad}}$ the adsorption equilibrium constant. At low initial organic compound concentrations and when adsorption is small, $\mathrm{K}_{\mathrm{ad}} \mathrm{C}$ is negligible and the model is reduced to equation 11, where $\mathrm{K}_{\mathrm{app}}=\mathrm{k}_{\mathrm{r}} \mathrm{K}_{\mathrm{ad}}$ is the apparent rate constant. ${ }^{25}$

$\ln \frac{\mathrm{C}_{0}}{\mathrm{C}}=\mathrm{k}_{\mathrm{r}} \mathrm{K}_{\mathrm{ad}} \mathrm{t}=\mathrm{K}_{\mathrm{app}} \mathrm{t}$
In this model, the slope of the $\ln \left(\mathrm{C}_{0} / \mathrm{C}\right) v s$. time $(\mathrm{t})$ plot is the apparent rate constant $\left(\mathrm{K}_{\text {app }}\right)$. Figure 9 presents results of phenol photodegradation kinetic studies that were used to determine apparent rate constants $\left(\mathrm{K}_{\text {app }}\right)$ and phenol half-lives $\left(\mathrm{t}_{1 / 2}\right)$. The half-life time $\left(\mathrm{t}_{1 / 2}\right)$ (the time at which $\mathrm{C}=0.5 \mathrm{C}_{0}$ ) is one of the most useful values to compare pseudo-first-order reaction rates (equation 12): $:^{71}$

$\mathrm{t}_{1 / 2}=\frac{\ln 2}{\mathrm{~K}_{\text {app }}}$

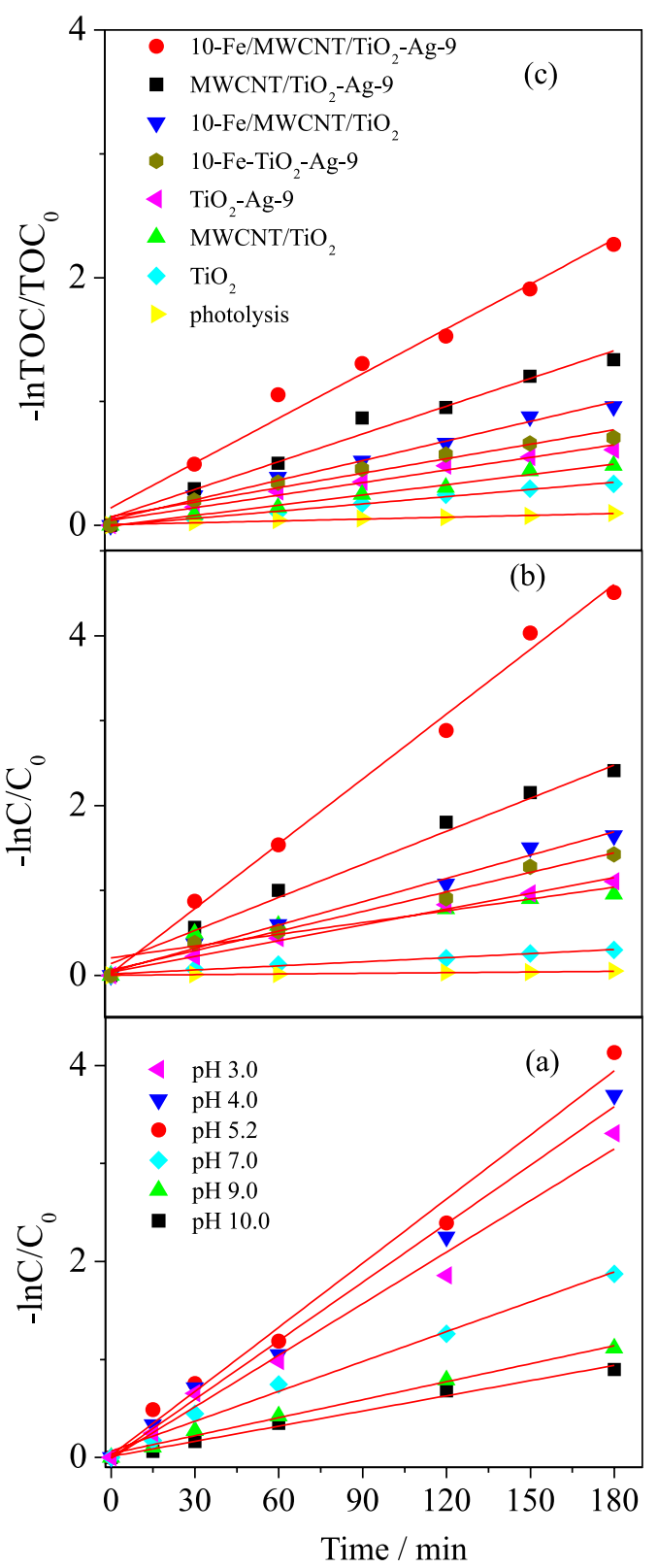

Figure 9. Pseudo-first-order degradation kinetics for phenol used to estimate Langmuir-Hinshelwood coefficients. Phenol removals: (a) with the catalyst $10-\mathrm{Fe} / \mathrm{MWCNT}_{\mathrm{TiO}}-\mathrm{Ag}-9$ at various $\mathrm{pH}$ levels, (b) with different photocatalysts by HPLC-DAD and (c) TOC. Reaction conditions: initial phenol concentration of $50 \mathrm{mg} \mathrm{L}^{-1}, 300 \mathrm{mg}$ of photocatalyst and reaction temperature $30 \pm 2{ }^{\circ} \mathrm{C}$. 
Table 2. Langmuir-Hinshelwood apparent rate constants $\left(\mathrm{K}_{\text {app }}\right)$, half-life $\left(\mathrm{t}_{1 / 2}\right)$ and coefficients of determination $\left(\mathrm{R}^{2}\right)$ for the photodegradation of phenol measured by HPLC-DAD and TOC

\begin{tabular}{|c|c|c|c|c|c|c|}
\hline & \multicolumn{3}{|c|}{ HPLC-DAD ${ }^{\mathrm{a}}$} & \multicolumn{3}{|c|}{$\mathrm{TOC}^{\mathrm{b}}$} \\
\hline & $\mathrm{K}_{\mathrm{app}} / \min ^{-1}$ & $\mathrm{t}_{1 / 2} / \min$ & $\mathrm{R}^{2}$ & $\mathrm{~K}_{\text {app }} / \min ^{-1}$ & $\mathrm{t}_{1 / 2} / \min$ & $\mathrm{R}^{2}$ \\
\hline Photolysis & 0.0005 & 1414.6 & 0.983 & 0.0003 & 2682.2 & 0.992 \\
\hline $\mathrm{TiO}_{2}$ & 0.0020 & 355.5 & 0.989 & 0.0016 & 430.5 & 0.976 \\
\hline $\mathrm{TiO}_{2}$-Ag-9 & 0.0062 & 111.9 & 0.999 & 0.0034 & 203.9 & 0.987 \\
\hline $10-\mathrm{Fe}-\mathrm{TiO}_{2}-\mathrm{Ag}-9$ & 0.0077 & 90.1 & 0.982 & 0.0039 & 177.7 & 0.975 \\
\hline $\mathrm{MWCNT}^{-\mathrm{TiO}_{2}}$ & 0.0032 & 216.6 & 0.992 & 0.0028 & 247.6 & 0.988 \\
\hline $10-\mathrm{Fe} / \mathrm{MWCNT} / \mathrm{TiO}_{2}$ & 0.0092 & 75.8 & 0.989 & 0.0053 & 130.8 & 0.978 \\
\hline $\mathrm{MWCNT} / \mathrm{TiO}_{2}-\mathrm{Ag}-9$ & 0.0130 & 53.4 & 0.989 & 0.0075 & 92.4 & 0.979 \\
\hline 10-Fe/MWCNT/TiO ${ }_{2}-\mathrm{Ag}-9$ & 0.0255 & 27.2 & 0.982 & 0.0120 & 57.8 & 0.978 \\
\hline
\end{tabular}

${ }^{\mathrm{a} H P L C}-\mathrm{DAD}$ : high performance liquid chromatography with linear photodiode array detector; ${ }^{\mathrm{b}} \mathrm{TOC}$ : total organic carbon.

The kinetic data for $\mathrm{pH}$ variation (Figure 9a), phenol photodegradation by HPLC-DAD (Figure 9b) and TOC photodegradation (Figure 9c) results adjusted well to the pseudo-first-order kinetic model, with coefficients of determination $\left(\mathrm{R}^{2}\right)$ higher than 0.97 .

Apparent rate constants $\left(\mathrm{K}_{\text {app }}\right)$, half-life times $\left(\mathrm{t}_{1 / 2}\right)$ and the coefficients of determination $\left(\mathrm{R}^{2}\right)$ are summarized in Tables 2 and S2 (in the SI section).

Figure 9a and Table S2 show that the highest phenol photodegradation rate is between $\mathrm{pH} 3.00-5.20$ $\left(\mathrm{K}_{\text {app }}=0.018\right.$ to $0.025 \mathrm{~min}^{-1}$ and $\mathrm{t}_{1 / 2}=38.5$ to $\left.27.7 \mathrm{~min}\right)$, and the smallest photodegradation rates occur at $\mathrm{pH}$ levels exceeding 5.2. The values obtained for $\mathrm{pH} 7$ and 10 are $\mathrm{K}_{\text {app }}=0.012$ and $0.006 \mathrm{~min}^{-1}$, and $\mathrm{t}_{1 / 2}=57.8$ and $115.5 \mathrm{~min}$, respectively. The degradation rate is influenced by the solution $\mathrm{pH}$, where the lowest rates are at $\mathrm{pH}>\mathrm{pH}_{\mathrm{ZPC}}$ $\left(\mathrm{pH}_{\mathrm{ZPC}}>5.49\right)$ for the catalyst.

In Figures $9 \mathrm{~b}$ and $9 \mathrm{c}$, when comparing the $\mathrm{TiO}_{2}$ reaction rates with other catalysts, it is clear that the incorporation of MWCNT, $\mathrm{Fe}$ and $\mathrm{TiO}_{2}-\mathrm{Ag}$ in preparation of the catalyst 10-Fe/MWCNT/TiO 2 -Ag-9 promoted an improvement in the kinetics of phenol photodegradation.

There was an increase in the reaction speed of 12.5 times with $\mathrm{K}_{\text {app }}\left(\mathrm{TiO}_{2}\right)=0.0020 \mathrm{~min}^{-1}$ to $\mathrm{K}_{\text {app }}$ $\left(10-\mathrm{Fe} / \mathrm{MWCNT} / \mathrm{TiO}_{2}-\mathrm{Ag}-9\right)=0.0255 \mathrm{~min}^{-1}$. Half-lives of $216.6 \mathrm{~min}$ (phenol by HPLC-DAD) and $247.6 \mathrm{~min}$ (TOC) were found for the photodegradation with the MWCNT-TiO ${ }_{2}$ composite. The incorporation of Fe or Ag on $\mathrm{MWCNT} / \mathrm{TiO}_{2}$ increased the reaction rate, with half-life for $10-\mathrm{Fe} / \mathrm{MWCNT} / \mathrm{TiO}_{2}$ and $\mathrm{MWCNT} / \mathrm{TiO}_{2}-\mathrm{Ag}-9$ of 75.8 and $53.4 \mathrm{~min}$ (phenol by HPLC-DAD), and 130.8 and $92.4 \mathrm{~min}$ (TOC), respectively. The simultaneous incorporation of $\mathrm{Fe}$ and $\mathrm{Ag}$ on $\mathrm{MWCNT}-\mathrm{TiO}_{2}$ forming the composite $10-\mathrm{Fe} / \mathrm{MWCNT} / \mathrm{TiO}_{2}-\mathrm{Ag}-9$ reduces the half-lives to $27.2 \mathrm{~min}$ (phenol by HPLC-DAD) and
$57.8 \mathrm{~min}$ (TOC), corresponding to $\mathrm{K}_{\text {app }}=0.0255 \mathrm{~min}^{-1}$ (phenol by HPLC-DAD) and $0.0120 \mathrm{~min}^{-1}$ (TOC). Wang et al..$^{27}$ reported phenol photodegradation by 20-MWCNT- $\mathrm{TiO}_{2}$ of $96 \%$ (initial concentration of $50 \mathrm{mg} \mathrm{L}^{-1}$ ) after $5 \mathrm{~h}$ with $\mathrm{K}_{\text {app }}=0.0074 \mathrm{~min}^{-1}$ and $\mathrm{t}_{1 / 2}=93$ min. Almeida et al.${ }^{25}$ evaluated phenol degradation (initial concentration of $50 \mathrm{mg} \mathrm{L}^{-1}$ ) by $\mathrm{TiO}_{2} / \mathrm{MgZnAl}-5$ after $6 \mathrm{~h}$, with $\mathrm{K}_{\text {app }}=0.0114 \mathrm{~min}^{-1}$ and $\mathrm{t}_{1 / 2}=60.8 \mathrm{~min}$. In the study by Chiou et al. ${ }^{70}$ using $\mathrm{TiO}_{2} \mathrm{P}-25$, a phenol degradation of $84 \%$ was reported (initial concentration of $50 \mathrm{mg} \mathrm{L}^{-1}$ ) in $3 \mathrm{~h}$ with $\mathrm{K}_{\text {app }}=0.014 \mathrm{~min}^{-1}$ and $\mathrm{t}_{1 / 2}=49.3$ min using a $400 \mathrm{~W}$ UV lamp and addition of $\mathrm{H}_{2} \mathrm{O}_{2}\left(0.05 \mathrm{mg} \mathrm{L}^{-1}\right)$. Therefore, one can conclude that the 10-Fe/MWCNT/TiO 2 -Ag-9 composite photocatalyst showed satisfactory kinetic performance with the potential to eliminate phenolic compounds in an aqueous medium.

\section{Reuse}

For the purpose of practical application, it is necessary to evaluate the reuse and stability of the catalyst. The reuse studies were performed with recovery of the material (300 mg), maintaining constant all other parameters. Thus, the efficiency of $10-\mathrm{Fe} / \mathrm{MWCNT} / \mathrm{TiO}_{2}-\mathrm{Ag}-9$ was evaluated by 10 reuse tests lasting $3 \mathrm{~h}$ each, totaling $30 \mathrm{~h}$ of study. The results showed that the catalyst presented good photocatalytic activity even after ten consecutive cycles. The yield for degradation of phenol was $100 \%$ in the first test and decreased to $92 \%$ in the tenth test (final test). Thus, the $10-\mathrm{Fe} / \mathrm{MWCNT}_{\mathrm{TiO}}{ }_{2}$-Ag-9 catalyst remained stable, presenting an $8 \%$ decrease in phenol degradation efficiency after ten consecutive photocatalytic cycles.

Electron microscopy (Figure S2d), energy dispersive spectroscopy (Figure S3d), X-ray diffraction (Figure 1f) and infrared spectroscopy (Figure 2e) were used to evaluate 
the stability of the catalyst. The results showed that there was no change in the chemical/physical characteristics of the $10-\mathrm{Fe} / \mathrm{MWCNT} / \mathrm{TiO}_{2}-\mathrm{Ag}-9$ catalyst after ten consecutive photocatalytic cycles.

\section{Conclusions}

A magnetically recoverable catalyst, 10-Fe/MWCNT/TiO $2-A g-9$, was successfully synthesized in this work. The photocatalysts were used in UV-Vis (cut off filter $>300 \mathrm{~nm}$ ) photodegradation of phenol in aqueous solution and presented high photocatalytic activity. The 10-Fe/MWCNT/TiO $2-\mathrm{Ag}-9$ composite photocatalyst resulted in approximately $100 \%$ phenol and $85 \%$ TOC removal from an aqueous phenol solution of initial concentration equal to $50 \mathrm{mg} \mathrm{L}^{-1}$, after $180 \mathrm{~min}$.

The 10-Fe/MWCNT/TiO 2 -Ag-9 catalyst showed good stability after 10 cycles, thus showing promising potential for practical applications. Phenol removal with the novel catalyst was greater than that obtained with commercial $\mathrm{TiO}_{2}$ (Degussa P25) because of its smaller band-gap energy $(2.24 \mathrm{eV}$ vs. $3.20 \mathrm{eV})$ and lower electron-hole pair recombination rate due to the presence of silver, iron oxide and MWCNT. Since the 10-Fe/MWCNT/ $\mathrm{TiO}_{2}$-Ag-9 photocatalyst shifted light absorption to a higher wavelength, less energy was required for photocatalytic activity and the phenol removal efficiency increased. Moreover, iron oxide makes the catalyst magnetic, so that, it is easily separated from the solution by applying an external magnetic field. The new photocatalysts showed a combined effect of the MWCNT support, the presence of iron oxide associated to the $\mathrm{TiO}_{2}-\mathrm{Ag}$ photoactivity, resulting in formation of a composite with high photocatalytic capacity.

\section{Supplementary Information}

Supplementary data (annular photoreactor, SEM, EDS, photodegradation of phenol by catalysts with supported $\mathrm{TiO}_{2}$ and Langmuir-Hinshelwood apparent rate constants) are available free of charge at http://jbcs.sbq.org.br as PDF file.

\section{Acknowledgments}

The authors acknowledge the financial support of the Fundação de Amparo à Pesquisa do Estado de Minas Gerais (FAPEMIG, Universal Demand, process No. APQ-00445-14) and the Conselho Nacional de Desenvolvimento Científico e Tecnológico (CNPq). We also thank the Laboratory of Nanomaterials of the DF/ UFMG for providing the multi-walled carbon nanotubes.

\section{References}

1. Fox, M. A.; Dulay, M. T.; Chem. Rev. 1993, 93, 341.

2. Liu, J.; Bai, H.; Wang, Y.; Liu, Z.; Zhang, X.; Sun, D. D.; Adv. Funct. Mater. 2010, 20, 4175.

3. Almeida, L. C.; Zanoni, M. V. B.; J. Braz. Chem. Soc. 2014, 25,579 .

4. Ouyang, K.; Xie, S.; Ma, X.; Ceram. Int. 2013, 39, 7531.

5. Gui, M. M.; Wong, W. M. P.; Chai, S.-P.; Mohamed, A. R.; Chem. Eng. J. 2015, 278, 272.

6. Devi, L. G.; Nagaraj, B.; Rajashekhar, K. E.; Chem. Eng. J. 2012, 181-182, 259.

7. Sobana, N.; Selvam, K.; Swaminathan, M.; Sep. Purif. Technol. 2008, 62, 648.

8. Stropa, J. M.; Herrero, A. S.; Oliveira, S. C.; Cavalheiro, A. A.; Dantas, F.; Oliveira, S. L.; Oliveira, L. C. S.; J. Braz. Chem. Soc. 2016, 27, 575.

9. Luo, Y.; Lu, Z.; Jiang, Y.; Wang, D.; Yang, L.; Huo, P.; Da, Z.; Bai, X.; Xie, X.; Yang, P.; Chem. Eng. J. 2014, 240, 244.

10. Woan, B. K.; Pyrgiotakis, G.; Sigmund, W.; Adv. Mater. 2009, $21,2233$.

11. Ou, Y.; Lin, J.; Fang, S.; Liao, D.; Chem. Phys. Lett. 2006, 429, 199.

12. Gui, M. M.; Chai, S. P.; Xu, B. Q.; Mohamed, A. R.; Sol. Energy Mater. Sol. Cells 2014, 122, 183.

13. Xin, T.; Ma, M.; Zhang, H.; Gu, J.; Wang, S.; Liu, M.; Zhang, Q.; Appl. Surf. Sci. 2014, 288, 51.

14. Zhou, H.; Zhang, C.; Wang, X.; Li, H.; Du, Z.; Synth. Met. 2011 , $161,2199$.

15. Etacheri, V.; Di Valentin, C.; Schneider, J.; Bahnemann, D.; Pillai, S. C.; J. Photochem. Photobiol., C 2015, 25, 1.

16. Luo, Y.; Lu, Z.; Yinhua, J.; Wang, D.; Yang, L.; Huo, P.; Da, Z.; Bai, X.; Xie, X.; Yang, P.; Chem. Eng. J. 2014, 240, 244.

17. Zhang, P.; Mo, Z.; Han, L.; Wang, Y.; Zhao, G.; Zhang, C.; J. Mol. Catal. A: Chem. 2015, 402, 17.

18. Aguilar, C. A. H.; Pandiyan, T.; Arenas-Alatorre, J. A.; Singh, N.; Sep. Purif. Technol. 2015, 149, 265.

19. Yin, H.; Dai, X.; Zhu, M.; Li, F.; Feng, X.; Liu, F.; J. Hazard. Mater. 2015, 296, 221.

20. Toledo, T. V.; Bellato, C. R.; do Rosário, R. H.; Marques Neto, J. O.; Quim. Nova 2011, 34, 561.

21. Devi, L. G.; Reddy, K. M.; Appl. Surf. Sci. 2011, 257, 6821.

22. Lin, K. N.; Liou, W. J.; Yang, T. Y.; Lin, H. M.; Lin, C. K.; Chien, S. H.; Chen, W. C.; Wu, S. H.; Diamond Relat. Mater. 2009, 18, 312 .

23. Zhou, D.; Ding, L.; Cui, H.; An, H.; Zhai, J.; Li, Q.; J. Power Sources 2013, 222, 510.

24. Wang, X.; Wu, P.; Lu, Y.; Huang, Z.; Zhu, N.; Lin, C.; Dang, Z.; Sep. Purif. Technol. 2014, 132, 195.

25. Almeida, F. M.; Bellato, R. C.; Honor, A.; Olavo, S.; Milagres, L. J.; Miranda, D. L. L.; Appl. Surf. Sci. 2015, 357, 1765. 
26. Li, H.; Ma, Y.; Niu, R.; Sep. Purif. Technol. 2016, 171, 93.

27. Wang, W.; Serp, P.; Kalck, P.; Lu, J.; J. Mol. Catal. A: Chem. 2005, 235, 194.

28. Rather, S.; Mehrajuddin, N.; Zacharia, R.; Hwang, S. W.; Kim, A. R.; Nahm, K. S.; Int. J. Hydrogen Energy 2009, 34, 961.

29. Ai, L.; Jiang, J.; Chem. Eng. J. 2012, 192, 156.

30. Quiñones, D. H.; Rey, A.; Álvarez, P. M.; Beltrán, F. J.; Plucinski, P. K.; Appl. Catal., B 2014, 144, 96.

31. Kim, C.; J. Ind. Eng. Chem. (Amsterdam, Neth.) 2015, 31, 43.

32. Wang, H.; Cao, L.; Yan, S.; Huang, N.; Xiao, Z.; Mater. Sci. Eng., B 2009, 164, 191.

33. Miranda, L. D. L.; Bellato, C. R.; Milagres, J. L.; Moura, L. G.; Mounteer, A. H.; de Almeida, M. F.; J. Environ. Manage. 2015, $156,225$.

34. Aysin, B.; Ozturk, A.; Park, J.; Ceram. Int. 2013, 39, 7119.

35. Yang, Y.; Liu, E.; Dai, H.; Kang, L.; Wu, H.; Int. J. Hydrogen Energy 2013, 39, 7664.

36. Pugazhenthiran, N.; Murugesan, S.; Anandan, S.; J. Hazard. Mater. 2013, 263, 541.

37. Koo, Y.; Littlejohn, G.; Collins, B.; Yun, Y.; Shanov, V. N.; Schulz, M.; Pai, D.; Sankar, J.; Composites Part B 2014, 57, 105 .

38. Aazam, E. S.; Ceram. Int. 2014, 40, 6705.

39. Stéfani, D.; Paula, A. J.; Vaz, B. G.; Silva, R. A.; Andrade, N. F.; Justo, G. Z.; Ferreira, C. V.; Filho, A. G. S.; Eberlin, M. N.; Alves, O. L.; J. Hazard. Mater. 2011, 189, 391.

40. Saleh, T. A.; Gupta, V. K.; J. Colloid Interface Sci. 2011, 362 , 337.

41. Anbarasu, M.; Anandan, M.; Chinnasamy, E.; Gopinath, V.; Balamurugan, K.; Spectrochim. Acta, Part A 2015, 135, 536.

42. Zhang, X.; Lei, L.; J. Hazard. Mater. 2008, 153, 827.

43. Froment, F.; Tournié, A.; Colomban, P.; J. Raman Spectrosc. 2008, 39, 560 .

44. Neff, D.; Ludovic, B.-G.; Philippe, D.; Solen, R.; Ludovic, L.; J. Raman Spectrosc. 2007, 38, 1538.

45. Ma, L.; Chen, A.; Lu, J.; Zhang, Z.; He, H.; Li, C.; Particuology 2014, 14, 24.

46. Nossol, A. B. S.; Suzamar, M. C. R. S.; Nossol, E.; Zarbin, A. J. G.; Peralta-Zamora, P.; Quim. Nova 2016, 10, 1.

47. Jaafar, N. F.; Jalil, A. A.; Triwahyono, S.; Efendi, J.; Mukti, R. R.; Jusoh, R.; Jusoh, N. W. C.; Karim, A. H.; Salleh, N. F. M.; Suendo, V.; Appl. Surf. Sci. 2015, 338, 75.

48. Gao, B.; Jiang, Z.; Zhao, C.; Gomaa, H.; Pan, F.; J. Membr. Sci. 2015, 492, 230.

49. Choudhury, B.; Choudhury, A.; Mater. Chem. Phys. 2012, 132, 1112.

50. Calandra, P.; Lombardo, D.; Pistone, A.; Liveri, V. T.; Trusso, S.; J. Nanopart. Res. 2011, 13, 5833.

51. Liu, S. S.; Sun, H.; Liu, S. S.; Wang, S.; Chem. Eng. J. 2013, 214, 298.
52. Sampaio, M. J.; Silva, C. G.; Marques, R. R. N.; Silva, A. M. T.; Faria, J. L.; Catal. Today 2011, 161, 91.

53. Tang, Y.; Zhang, G.; Liu, C.; Luo, S.; Xu, X.; Chen, L.; Wang, B.; J. Hazard. Mater. 2013, 252-253, 115.

54. He, J.; Ichinose, I.; Kunitake, T.; Nakao, A.; Langmuir 2002, 18, 10005.

55. Harifi, T.; Montazer, M.; Ultrason. Sonochem. 2015, 27, 543.

56. Harifi, T.; Montazer, M.; Appl. Catal., A 2014, 473, 104.

57. Jia, X.; Dai, R.; Lian, D.; Han, S.; Wu, X.; Song, H.; Appl. Surf. Sci. 2017, 392, 268.

58. Ghavami, M.; Mohammadi, R.; Koohi, M.; Kassaee, M. Z.; Mater. Sci. Semicond. Process. 2014, 26, 69.

59. Tang, Y.; Luo, S.; Teng, Y.; Liu, C.; Xu, X.; Zhang, X.; Chen, L.; J. Hazard. Mater. 2012, 241-242, 323.

60. Yeh, N.; Lee, Y. C.; Chang, C. Y.; Cheng, T. C.; Thin Solid Films 2013, 549, 93.

61. Lu, Z.; Chen, F.; He, M.; Song, M.; Ma, Z.; Shi, W.; Yan, Y.; Lan, J.; Li, F.; Xiao, P.; Chem. Eng. J. 2014, 249, 15.

62. Yu, J.; Yu, H.; Ao, C. H.; Lee, S. C.; Yu, J. C.; Ho, W.; Thin Solid Films 2006, 496, 273.

63. McManamon, C.; Holmes, J. D.; Morris, M.; J. Hazard. Mater. 2011, 193, 120.

64. Khraisheh, M.; Wu, L.; Al-Muhtaseb, A. H.; Albadarin, A. B.; Walker, G. M.; Chem. Eng. J. 2012, 213, 125.

65. Nogueira, R. F. P.; Jardim, W. F.; Quim. Nova 1998, 2, 69.

66. Sclafani, A.; Herrmann, J.-M.; J. Photochem. Photobiol., A 1998, 113, 181.

67. Zhao, W.; Zhang, J.; Zhu, X.; Zhang, M.; Tang, J.; Tan, M.; Wang, Y.; Appl. Catal., B 2014, 144, 468.

68. Liu, W.; Zhao, X.; Borthwick, A. G. L.; Wang, Y.; Ni, J.; ACS Appl. Mater. Interfaces 2015, 17, 19726.

69. Liu, W.; Ni, J.; Yin, X.; Water Res. 2014, 53, 12.

70. Chiou, C.; Wu, C.; Juang, R.; Chem. Eng. J. 2008, 139, 322.

71. Shaban, Y. A.; El Sayed, M. A.; El Maradny, A. A.; Al Farawati, R. Kh.; Al Zobidi, M. I.; Chemosphere 2013, 91, 307.

72. Grabowska, E.; Sobczak, J. W.; Gazda, M.; Zaleska, A.; Appl. Catal., B: Environ. 2012, 117-118, 351.

73. Ling, H.; Kim, K.; Liu, Z.; Shi, J.; Zhu, X.; Huang, J.; Catal. Today 2015, 258, 96.

74. Mohamed, M. A.; Salleh, W. N. W.; Jaafar, J.; Ismail, A. F.; Nor, N. A. M.; Mater. Chem. Phys. 2015, 162, 113.

75. Murcia, J. J.; Hidalgo, M. C.; Navío, J. A.; Araña, J.; Doña-Rodríguez, J. M.; Appl. Catal., B: Environ. 2015, 179, 305.

76. Qiu, R.; Zhang, D.; Diao, Z.; Huang, X.; He, C.; Morel, J.-L.; Xiong, Y.; Water Res. 2012, 46, 2299.

77. Andrade, M. A.; Carmona, R. J.; Mestre, A. S.; Matos, J.; Carvalho, A. P.; Ania, C. O.; Carbon 2014, 76, 183.

Submitted: March 3, 2017

Published online: May 5, 2017 